\title{
Let us try to assume our fundamental ambiguity: on the art of getting beyond identity politics
}

\author{
Pascal Gielen' \\ http://orcid.org/0000-0003-2846-4328 \\ I - Univesiteit Antwerpen \\ Antwerp, Belgium
}

\begin{abstract}
Inspired by Antonio Gramsci, sociologist Pascal Gielen defines the last decade as one of 'organic crisis'. In such periods many (economic, political, ecological) crisis follow each other while the hegemonic order cannot deal with them anymore in a convincing way, and a new political paradigm that can sufficiently deal with them is not yet invented. In such a period the oppositions between left and right, between different ethnic groups, or between genders start to become more black \& white. That's why Gielen thinks also identity politics is problematic, or has at least a very problematic flip side that is contra-productive for finding solutions for this crisis. Instead we need to develop a so-called ambiguity politics inspired by ambiguity aesthetics, that could deal in a better way with the problems and contradictions of this contemporary world of rambling causalities. Such a politics is based on the recognition of the Other in ourselves, and on the understanding of ourselves and our societies as fundamentally ambiguous.
\end{abstract}

Keywords: ambiguity politics; identity politics; organic crisis; aesthetic ambiguity.

Resumo: Vamos assumir nossa ambiguidade fundamental: sobre a arte de ir para além das políticas identitárias - Inspirado por Antonio Gramsci, o sociólogo Pascal Gielen define a última década como uma "crise orgânica". Nesse período, diversas crises (econômicas, políticas, ecológicas) seguiram umas às outras; ao mesmo tempo, a ordem hegemônica não consegue mais lidar com tais crises de modo convincente e não foi ainda inventado um novo paradigma político que possa suficientemente debruçar-se sobre elas. Nessa última década, as oposições entre esquerda e direita, entre diferentes grupos étnicos ou gêneros, começam a distinguir aquilo que é certo e o que é errado. Este é o porquê Gielen considera a política identitária também problemática, ou ao menos que possui um lado contraprodutivo para encontrar soluções para a crise em questão. Ao contrário da política identitária, devemos desenvolver o que é chamado aqui de política da ambiguidade, que tem inspiração na ambiguidade estética, 
a qual consegue lidar melhor com problemas e contradições de um mundo contemporâneo de causalidades desmedidas. Tal política é baseada no reconhecimento de um Outro em nós mesmos e em um entendimento fundamentalmente ambíguo de nós e de nossas sociedades.

Palavras-chave: política da ambiguidade; política identitária; crise orgânica; ambiguidade estética.

"Let us try to assume our fundamental ambiguity" Simone de Beauvoir (1947, p. 8)

"The irony of the logic of identity is that by seeking to reduce differently similar to the same, it turns the merely different into the absolutely other" Irin Marion Young (1999, p. 99)

\section{Monsters}

The power of identity politics, whether coming from feminist, ethnical, or nationalistic quarters, is that it generates energy for civil fight and political action. Those who feel that their individuality is not recognized, or not even acknowledged, tend to feel an urge towards articulation and identification. Slogans such as 'Black Lives Matter', 'My Body, My Choice', but also 'Leuven Flemish' result from a quest to find means and especially meanings to signify oneself. Culture and only culture provides the 'repertoire' of signs to set such a signifying process in motion (GIELEN, 2015). However, this process is always preceded by as yet undefined and therefore still unclear feelings of discontent, aversion, or sometimes even depression. Suppression and also collective repression do after all hinder subordinates in focusing their emotions. The transformation of hard to interpret affects, of feelings whose origin we find difficult to trace, but also of focused passions such as the wish for clear articulation may sometimes be in line with what Karl Marx has called the transition of Klasse an sich to Klasse für sich. And although the theory of social classes is often used to point out the problematic side of identity politics, the latter does take its cue from a similar mechanism. After all, doesn't class consciousness arise precisely by articulating an identity, however international this identity may be? The Klasse an sich can only free itself from its unpleasant situation by first identifying and expressing itself [MARX,1974 (1867)]. Like articulation and identification, expression is an essential step in any stage of emancipation.

The societal debate of the last century is hard to imagine without the problematics of identity and identification. How such identity logics exactly work has been the study object of many of the humanities, from philosophy, semiotics, psychoanalysis, anthropology, and sociology to cultural studies. Those studies have resulted in at least two helpful notions, specifically Jacques Derrida's 'differance' (1967) and Paul Vandenbroek's 'negative 
self-definition' (1987). As is common knowledge among philosophers, Derrida's homophonic 'differance' in French means both 'delay' and 'difference'. The meaning of a word only arises in delay, in which a particular word can only come after another word, and distinct from previous or future words. Meaning, in other words, only arises relationally and is therefore a matter of convention, not of essence or substance. More broadly: it is not a natural but a cultural thing. In short, the relation between signifier and signified is arbitrary. These are by now well-known but also somewhat worn-out insights from semiotics. Still, understanding the formal play between signifier, signified, and meaning remains quite valuable in understanding the mechanisms of identity politics. For example, in Gender Trouble Judith Butler based her constructivist theory about the difference between women and men on it (BUTLER, 1990). The biological difference in gender pales compared to the distinction between, for example, feminine and masculine traits, or matriarchal and patriarchal structures. Or, a man can also act feminine and a woman can also run a patriarchal organization - you know, as Margaret Thatcher did. Identity is indeed not a matter of nature, but of culture. This also means that it is always relative, as identity can only exist because it has a relationship with other identities.

With an analysis of the paintings of Hieronymus Bosch, Pieter Breugel the Elder, and others, in the mid-1980s Paul Vandenbroek added another important insight: meaning is not only constructed in the formal difference from another meaning. Especially in identity forming, making a distinction usually happens in a negative and normative manner, hence Vandenbroek's 'negative self-definition' (1987). What happens is that one defines one's own identity by ascribing negative attributes to others in order to then create a positive mirror image of oneself. In other words, the construction of identity does not exclusively arise from a distinction between us and the other, but also from that between a better ' $w e^{\prime}$ versus a worse or inferior 'they'. At least one's own values and norms are seen as better or 'more fitting' for oneself then those of the other. The multicultural discourse partly relies on the latter reasoning: everyone is entitled to their own values, norms, and lifestyle, as long I may cherish mine or we ours, or as long as ours are not threatened. However, no matter how negative or different the others are painted in order to both distance and confirm our own identity, the reference to the other always remains anchored in our own identity. Just like 'we' need 'them', the word 'wo-man' needs the stem 'man'. Or, as psychoanalyst Julie Kristeva (1991) puts it: the other is always already inside ourselves, we are our own stranger. The thing that we don't want to be is, paradoxically, always already part of ourselves, no matter how hard we try to repress it. Taking this thought to its logical conclusion, it means, for example, that in every woman there is also a man, that Christianity also includes Islam, that democracy cannot exist without an undemocratic momentum, that the constitution needs a-legal legislators, that a socialist also - secretly or not - harbours liberal ideals, and of course the reverse of all this. As we know from Bruno Latour's ActorNetwork Theory: we are not either-or beings but and-and monsters (LATOUR, 1994). 
In short, ambiguity is the rule and, who knows, is even our true 'nature' and therefore a unique identity is nothing but culture. Or, less prosaically: the world consists of monsters, and pure beings only exist in the domain of the imaginary; only in fiction and art do we meet pure form; only in mathematics can the pure formula survive. By contrast, the empirical world is full of static. Reality is always more complex, more paradoxical, and perhaps much 'dirtier', but certainly more ambiguous.

\section{Why Relativism Doesn't Work in Politics}

Today, all identity theories need this relativism to maintain their own intellectual credibility, just like Butler secured academic feminism again with a hefty dose of constructivism. Relativism safeguards all identity claims against essentialism, substantialism, naturalism, and even fundamentalism. Still, things that are relatively easily construed in theory are often hard to achieve in everyday social life. "It is difficult to articulate positive elements of group affinity without essentializing them", feminist political scientist Irin Marion Young (2011, p. 172) admits. Especially in politics there always comes a moment at which the distinction between us and them becomes essentialistic and true ambiguity needs to be repressed. According to Dan Webb (2017) - following Chantal Mouffe and Jodi Dean - this is even the essence of politics. Politics cannot exist without exclusion, without what we wish and want for ourselves but not for 'them'. Nowadays, just about all integration policies are based on it, at least in the Global North. 'You can only enjoy our prosperity if you subscribe to our values and norms.' In short, 'you' must become 'us', which in fact makes integration a synonym for assimilation. It should come as no surprise then that nowadays liberal philosophers like Francis Fukuyama speak of assimilation instead of integration, without blinking an eye. The others must subscribe to a country's national values and norms if they wish to make use of the social benefits provided by that state (FUKUYAMA, 2019). If they do not comply, they will be permanently excluded. Apparently, politics needs that moment at which it can draw an essentialistic line between us and them, left and right, progressive and conservative. Politics draws strength from the momentum when the ranks are closed and all ambiguity is excluded. Webb:

\footnotetext{
[...] political decisions are always decisions of how power will be exerted, employed, or withheld. The moment of decision, a necessary prerequisite for political action, announces an antagonism, an "us versus them", and a willingness to avow the symbolic violence (WEBB, 2017, p. 65).
}

So, concrete politics has little use for constructivist and other post-modern thought experiments. One can hardly perform a difficult balancing act between feminine and masculine traits when composing, say, an administrative body or political party's leadership in a responsible manner. Or, one may attempt to 'de-patriarchilize' an organization 
or decision-making processes, but such an enterprise would be rather absurd if the organization concerned is an exclusively male club. In other words, everyday identity politics always resorts to substantial and sometimes of course also natural distinctions in order to draw a straight line. How else is one supposed to enforce a quota of fifty per cent women? In the fight for equality the fact that we are already present in the other and, vice versa, this alterity is present in us, isn't really particularly helpful. It is a too soft or ethical argument that simply doesn't work in politics. Again, politics needs a moment of concretization, 'substantialization', or at least essentialization. This is also true of purely cultural constructs such as language, cultural diversity, or national identity. In order to make decisions, to make laws and to take measures politics must always cut the knot. Who is an economic refugee and who a political one? Who is integrated and proficient enough in the language and who isn't? Who is living below the poverty line and who isn't? All distinctions are gradual and open to interpretation, but in the final political decision between who is and who isn't, a strict line is always drawn.

\section{The Pivoting Moment for Identity Politics}

If politics needs essentialistic claims, the same goes - perhaps even more so for identity politics. No matter how much feminist, postcolonial, or subaltern studies underline the relativity of identity constructs these days, both the activist and the politician will eventually have to resort to supposedly essential characteristics to guarantee a level playing field later. Striving for balance and equality is simply impossible without defining the unequals and therefore also not without pointing out a substantial difference (in treatment, colour, gender). And even though progressive academics know only too well that this attribution is also a matter of interpretation, the floating signifier will always have to arrive at a solidified meaning in order to perform a political act. This inevitable process of solidification does mean, however, that all emancipatory struggles always risk causing a conservative reflex. The emancipation of one section of the population can always turn into 'our-own-people-first' rhetoric; antiracism can turn into racist antiracism [SARTRE, 1976 (1949)]; community forming into gated communities; feminism into gynocentrism; belief into fundamentalism; and love into obsession. The line between such binaries can be very thin and one can always discern historical pivoting moments at which the emancipation fighters start to behave in exactly the same manner as the enemy they are fighting against. And such moments are particularly interesting: the phase in which critical analyses based on cultural and therefore relative characteristics turn into substantial and 'naturalized' claims. It is not so much the turn itself that is interesting but the moment just before it occurs. One hypothesis is that it is precisely at that undecided or entropic junction that we may find a different politics than the one that is based on identity. 


\section{Organic Crisis}

Ambiguity comes to the fore when we discover the otherness within ourselves. We can no longer ignore it, but we also don't know - yet - how to handle it. In other words, we have not yet articulated, defined, or labelled the other. In the realm of politics this takes the form of a liminal period of what Antonio Gramsci (1992) has once called 'an organic crisis'. According to him, such a crisis presents itself when an existing - political - system is terminal and a new one cannot yet be born. It is an interregnum that creates a kind of administrative vacuum in which all kinds of ecological, economic, political, and social crises occur in rapid succession for which the old ideology increasingly fails to provide acceptable or credible solutions. However, a new political paradigm cannot deliver this either, because it is not yet ready for it and cannot be satisfactorily articulated yet. One of the reasons for this is that such an articulation is substantially hampered by the representatives of the old system. Or, as mentioned earlier, repression works against articulation. It is during such a period of organic crisis that an emancipatory struggle can easily turn into what Gramsci calls 'Caesarism' (GRAMSCl, 1992, p. 276). The interbellum was such a period. But are we not finding ourselves in a similar juncture again today? Although still thumping the bible of the free market, neoliberalism is finding it increasingly difficult to provide answers to the ecological and social problems it is generating itself. At the same time, there is, for the time being, no articulation of a full and credible alternative, no matter how hard progressive forces or the political left are trying. Anyway, they have a hard time convincing the majority of the population. And this is the momentum at which characters such as Viktor Orbán, Recep Tayyip Erdogan, Jair Bolsonaro, or Donald Trump come to the fore. After not even a century, the engine of the liberal revolution is already misfiring and reactionary and authoritarian ideas are gaining ground again. The success of the aforementioned gentlemen can in any case be seen as a symptom of the truly uncertain and ambiguous phase we find ourselves in. The fact that some politicians are frenetically trying to board things up is perhaps the best proof that we are in fact in a state of entropy. Everybody knows that urgent decisions have to be taken; everybody knows we should be heading in a different direction and yet we remain stuck in a situation of indecisiveness and half measures.

It is typically in times of organic crisis when Caesarism pushes forward that other political possibilities are repressed. While polarization is growing and the gap between ideological sides is becoming wider and wider, the chance for real radical alternatives, paradoxically, evaporates. The opposing parties entrench themselves by, among other things, centralizing their own identity, as mentioned before. Sweet multiculturalism disintegrates into bitterly fighting monocultures because just like monoculturalism, multiculturalism was not satisfied with ambiguity. Traditionally, periods of organic crisis are not the best electoral times for give-and-take parties in the political centre. Everyone is looking for 
a way out within their own idea of what is right, and doxas and dogmas are accentuated on both sides. Typical of such periods, however, is that below the radar a growing liminal realm of unimaginable arenas, of unseen possibilities, and even of both ideologically and legally prohibited practices unfolds. This is a zone where the trusted compass between right and left, between conservative and progressive, between localism and globalism goes haywire because these political factors are no longer functioning, to quote Bruno Latour (LATOUR, 2018). This notwithstanding, it is on this grey, also a-legal terrain that ambiguous politics find fertile soil and truly new constitutions are being prepared. It is perhaps no coincidence that this is also the terrain where various social positions meet and where the distinction between professions becomes less sharp. Both laymen and experts as well as grassroots movements and established institutions find themselves in the same situation there, as the terrain is unknown to all of them and their futures are equally uncertain. This is where artists become politicians, judges start operating as activists, politicians as relief workers, doctors as resistance fighters, and 'objective' scientists as moral opinion leaders. As things above ground become increasingly rigid, underground heterogeneity and liquidity are on the rise. This also means that identities, including professional identities, transmute or even remain totally open sometimes. In other words, what appeared to be irreconcilable ideas and practices fuse together into the most natural conglomerate rates during Gramsci's periods of 'organic crisis'. What look like nothing but paradoxes and contradictions above ground, accumulates underground until the moment that this expanding mass has no alternative but to break through the floor.

\section{Aesthetical Ambiguity}

It is hardly surprising that during such periods artists often come forward. They are after all very talented and often very well-trained in both creating and handling ambiguity. They do so, for example, by designing a visual language or a form of word art that is open to multiple interpretations. Isn't that exactly where the difference between prose and poetry lies, especially in that zone where meanings and signifiers become floating. Artists with a too unambiguous or too evident message are in any case often criticized and accused of making 'bad' art or simply 'not art' at all. Being 'unambiguous', being 'preacher-ish' are still powerful invectives in art criticism. Perhaps this is why many artists prefer not to explain their work, preferring to leave its meaning 'open'. To an extent, ambiguity stands for quality in the contemporary professional art world. How different art is from politics in that regard. In politics, ambiguity tends to have a negative connotation. In political science the term 'ambiguity politics' refers primarily to the phenomenon of politicians not really speaking their mind in order to avoid electoral loss. Professional politicians often don't reveal their personal ideas or their preference for addressing certain social issues because they know that their views may not be very popular and may cost them votes. 
Aesthetic ambiguity might be accused of using the same tactics. Allowing for multiple interpretation could, after all, appeal to a larger and more diverse audience of art lovers. However, as we know from cultural-sociological research, only a small portion of the population responds to an alchemy of meanings and identities (BOURDIEU, 1974). A large majority actually avoids heterogeneity and doesn't endure ambiguity for very long. This is rather regrettable because at the same time scientific studies point to a solid positive correlation - although not a causal one - between on the one hand being able to handle ambiguity and ambiguous visual language and, on the other hand, being open to the other (FRENKEL-BRUNSWIK, 1949). For example, someone who knows how to deal with ambiguous codes and information is significantly less likely to build up a racist set of values than someone who doesn't. Those who know how to handle ambiguity also feel less need for coherence or understand better that the world around them and the times they live in are full of paradoxes and contradictions. In other words, they don't need to fully understand the world in order to live happily in it. It would be worthwhile to investigate whether ambiguity might be actively deployed in politics. To be absolutely clear: this does not refer to the abovementioned politicological views of not very sincere administrators, but to a politics that teaches people to actively deal with ambiguity, thereby deflating the myth of transparent identity. In order to understand what such politics might look like, it seems appropriate, for the above reasons, to take a look at the art world.

\section{One Man Standing}

On June 17, 2013, at 6 PM, Turkish performance artist Erdem Gündüz decides to stand still, all alone, for a month, at Istanbul's Taksim Square and stare at the - meanwhile demolished - Atatürk Cultural Centre. From the façade of the centre hangs a banner with the likeness of Mustafa Kemal Atatürk, the man who once made Turkey a secular state. Gündüz begins his action on the same day that the Erdogan government prohibits protests following the heavy riots in Gezi Park. The performer thus stands not only literally before Atatürk, but also symbolically diametrically opposite the Caesarism personified by Erdogan in his homeland. Gündüz does not carry a banner, does not chant slogans, and neatly complies with the ban on assembling by acting alone. All this makes his action most ambiguous, both for those happening to pass by and for the police. Is this a protest, art, or a meaningless act of a disturbed individual? Should the police intervene? Would that be right or even lawful? In any case, it took a while before bystanders began to notice the performer and started to twitter about him, alerting the police that something was afoot. Around 2 AM they finally did intervene because supporters were assembling around Gündüz and only then the action of the Turkish former was labelled a protest. It could only last as long as his identity remained fluid. Is he an artist, an activist, or just some lunatic? Only when the situation is identified, the action is terminated. Gündüz' act, whether or not political, 
artistic, or hopeless, does however teach us something about what may characterize a possible politics of ambiguity. The least we can learn from his performance is that such a politics must be playful, variable, urban, and even a tiny bit sexy.

It is obvious that Gündüz is performing. He does even more: he brings one of the by now well-known artistic tricks of conceptual dance outside the walls of the theatre, namely standing still. This play with the rules of art, this breaking with the convention that in a dance performance there should be dancing, is applied by Gündüz in public space. He is protesting without protesting. Or, rather, the performer ignores the known codes of activism, precisely in order to make his action a success. Just as the conceptual choreographer once managed to annoy a dance audience, Gündüz now does so with the passers-by in a square and certainly with the police, who have trouble identifying the matter. This playfulness is in sharp contrast with the gravity of activists who gradually entrench themselves in their own cause, their own right, their own identity. Gündüz too is fighting with indignation against the political situation but he doesn't posit his own 'right' against it. For instance, during his action the performer refuses to speak or identify himself. Afterwards, he tells the BBC: "I'm just one protester, I'm just one artist... I'm nothing". Gündüz opposes, clearly identifies a hostile 'they' but without flying his own political colours. Thanks to this playfulness he remains ambiguous and avoids ending up in bitterly vindictive rhetoric or dogmatism. That same playfulness also makes sure that his identity remains variable and this variability in turn guarantees that the play can continue to be played. Precisely because Gündüz refuses to play a single role or choose a single identity he remains fluid. He is not either an artist or an activist or a lunatic, but an artist and an activist and a lunatic and... nothing. This 'monstrous' aspect is what lends his action a certain erotic appeal. That what is left unsaid, what is indistinct, arouses curiosity. Whereas identity politics frequently repulses people by continuously harping on something, ambiguity politics seduces them by creating confusion. It anticipates the pleasure and excitement of being drawn from the safety of your routines, of being confronted with something that is unknown, incomprehensible, or surprising. Precisely because we do not know what to expect from ambiguity, we are tempted to flirt with it. Like someone parading the streets we want to know what's around the corner and then we want to know what's around the next corner. With the previously quoted Young we could indeed say that ambiguity politics is radically urban. The political scientist contrasts the city, in normative terms, with a community aspiring to a uniform identity, such as local communities or the nation state. An urban living environment, by contrast, does not consist of equals, not of people who recognize each other, but of a 'being together of strangers' (YOUNG, 2011, p. 237).

City dwellers are together, bound to one another, in what should be and sometimes is a single polity. Their being together entails some common problems and common interests, but they do not create a community of shared final ends, of mutual identification and reciprocity (YOUNG, 2011, p. 238). 
One cannot base a hyper-diverse and mobile city on a preconceived blueprint, nor can one base a policy on it. Ambiguity politics, by contrast, is satisfied with the fact that the world is full of loose ends. Unlike a canal with straight banks, this attitude provides a meandering river of possibilities. In a small-scale and modest way, Gündüz' action demonstrates how to break open this social horizon of multiple use and differentiation and keep it open. This always carries the risk of being ostracized and of losing one's own identity. Gündüz risks being rejected by the professional art world because his work may be labelled as pure activist or political from now on. At the same time, it is possible that activists and politicians do not accept him either because his action is not explicit enough, is too artistic, indeed too ambiguous. In other words, the performer risks falling in between known and predefined identities. Still, it seems necessary to experiment with such ambiguous practices, as perhaps they contain a key for addressing issues of monoculturalism and neonationalism, multiculturalism and identity politics. After all, out of the contradictions and segregations raised by such political formations rises an unstoppable 'in-between' category. This ambiguous population category is not meaningless like an empty signifier, but is on the contrary full of meaning as it is overpopulated with all those falling between the monocultures of the multicultural world. Precisely this subset, this overlap and fusion between different identities and cultures will define the future. Precisely this 'in-between' area is the compost for a mixture that will grow to become the new majority of the world population. This irreversibly growing reality will inevitably classify all forms of identity, monoculture, and multi-culture as superstitions that were once Enlightened. Realpolitik will then eventually push aside the ideology of the nation state and all other identity politics. Or, to put it somewhat paradoxically: here lies the constitution for a new monoculture, but this time it will be a hyper-heterogenous nation of ramshackle causalities. This is the realm of ambiguity, a geopolitical space the geos of which - to quote Latour (2018) once more - does not refer to a bordered-off terrain but to the entire Earth.

Pascal Gielen is full professor of sociology of art and politics at the Antwerp Research Institute for the Arts (Antwerp University - Belgium) where he leads the Culture Commons Quest Office (CCQO). Gielen is editor in-chief of the international book series Arts in Society. In 2016 he became laureate of the Odysseus grant for excellent international scientific research of the Fund for Scientific Research Flanders in Belgium. His research focuses on creative labour, the institutional context of the arts and on cultural politics. Gielen has published many books which are translated in English, Korean, Polish, Portuguese, Russian, Spanish and Turkish.

pascal.gielen@uantwerpen.be 


\section{References}

BEAUVOIR (de), S. The Ethics of Ambiguity. New York: Open Road, 1947/1976.

BOURDIEU, P. Les fractions de la classe dominante et les modes d'appropriation des oeuvres d'art. Information sur les sciences sociales, 13, nr. 3, p. 7-32, 1974.

BUTLER, J. Gender Trouble: feminism and the subversion of identity. New York \& London: Routledge, 1990.

DERRIDA, J. L’Ecriture et la difference. Paris: Seuil, 1967.

FRENKEL-BRUNSWIK, E. Intolerance of Ambiguity as an Emotional and Perceptual Variable, Journal of Personality, 18, p. 108-143, 1949.

FUKUYAMA, F. Identity: contemporary identity, politics and the struggle for recognition. London: Profile Books, 2019.

GIELEN, P. (Org.) No culture, no Europe: on the foundation of politics. Amsterdam: Valiz, 2015.

GRAMSCI, A. Prison notes. New York: Columbia University Press, 1992.

KRISTEVA, J. De vreemdeling in onszelf. Amsterdam: Atlas Contact, 1991.

LATOUR, B. Wij zijn nooit modern geweest. Amsterdam: Van Gennep, 1994.

LATOUR, B. Waar kunnen we landen? Politieke oriëntatie in het Nieuwe Klimaatregime. Amsterdam: Octavo, 2017.

MARX, K. Capital: a critique of political economy. Volume 1. New York: Vintage Books, 1974.

SARTRE, J-P. Black orpheus, Paris: Présence Africaine, 1976.

VANDENBROECK, P. Beeld van de andere, vertoog over het zelf: over wilden en narren, boeren en bedelaars. Antwerpen: Koninklijk museum voor schone kunsten, 1987.

WEBB, D. Critical urban theory, common property, and "the political": desire and drive in the city. New York \& London: Routledge, 2017.

YOUNG, I.M. Justice and the politics of difference. Princeton \& Oxford: Princeton University Press, 2011. 